\title{
Lung function after bilateral lower lobe lung volume reduction surgery for $\alpha_{1}$-antitrypsin emphysema
}

\author{
A.F. Gelb*, R.J. McKenna**, M. Brenner***, R. Fischel**, N. Zamel ${ }^{+}$
}

\begin{abstract}
Lung function after bilateral lower lobe lung volume reduction surgery for $\alpha_{1}$-antitrypsin Emphysema. A.F. Gelb, R.J. McKenna, M. Brenner, R. Fischel, N. Zamel. (C) ERS Journals Ltd 1999.

ABSTRACT: This study explores the mechanism(s) of airflow limitation following lung volume reduction surgery (LVRS) in patients with emphysema due to homozygous $\alpha_{1}$-antitrypsin (AT) deficiency.

Bilateral targeted lower lobe stapled LVRS using video thoracoscopy was performed in six patients (five males) aged $61 \pm 9$ yrs $\left(\right.$ mean \pm sD) with $\alpha_{1}$-AT emphysema.

Two patients received only a 6-month follow-up. However, four patients, at 22, 24, 27 and 36 months post-LVRS, noted relief from dyspnoea and increased walk tolerance. At $27 \pm 6$ months (mean \pm SD) post-LVRS, their forced expiratory volume in one second improved only from $30 \pm 2 \%$ of the predicted value (mean \pm SEM) before surgery to $33 \pm 1 \%$ pred after surgery. Yet, total lung capacity (TLC) decreased from $151 \pm 13$ to $127 \pm 10 \%$ pred; diffusing capacity increased from $35 \pm 9$ to $59 \pm 9 \%$ pred; and vital capacity increased from $68 \pm 10$ to $88 \pm 5 \%$ pred. In three patients, static lung elastic recoil at TLC increased from $1.1 \pm 0.15$ to $1.2 \pm 0.10 \mathrm{kPa}$. Using flow/pressure curves, the mechanism for expiratory airflow limitation pre-LVRS and the improvement noted post-LVRS could be primarily accounted for by the initial loss and subsequent increase in lung elastic recoil.

Bilateral lung volume reduction surgery provides modest physiologic improvement for 2-3 yrs in patients with $\alpha_{1}$-antitrypsin emphysema due to increases in lung elastic recoil.
\end{abstract}

Eur Respir J 1999; 14: 928-933.

In both the National Institutes of Health-sponsored National Heart, Lung, and Blood Institute multicentre study in nonrandomized patients with severe $\alpha_{1}$-antitrypsin (AT) deficiency [1] and a similar European study [2], when the initial forced expiratory volume in one second (FEV1) was $<35 \%$ of the predicted value, the subsequent decline in FEV1 in patients who had never received intravenous augmentation therapy did not differ from that in patients on weekly augmentation therapy. Moreover, use of augmentation therapy was not associated with a lower mortality rate [1]. Therefore, alternative therapeutic intervention has been sought.

Following targeted bilateral stapled lung volume reduction surgery (LVRS) for emphysema, variable improvement in exercise tolerance, oxygen usage and lung function has been noted at $\geq 2$ yrs following surgery [3-7]. However, only the data of CASSINA et al. [3] provide results in patients (12) with $\alpha_{1}$-AT deficiency emphysema. They noted transient improvement in FEV1 and static lung volumes at 6-12 months with further deterioration by 24 months post-LVRS. These results are in contrast to the improvement in FEV1 and static lung volumes at 24 months post-LVRS in patients with non $\alpha_{1}$-AT smokers emphysema, as noted by CASSINA et al. [3] as well as by other investigators [4-7].

Previous studies have demonstrated that expiratory airflow limitation in chronic cigarette smokers without $\alpha_{1}$-AT deficiency who undergo LVRS for predominantly upper
*Pulmonary Division Dept of Medicine, Lakewood Regional Medical Center, School of Medicine, University of California, Los Angeles; **Dept of Thoracic Surgery, Chapman Medical Center, Orange and School of Medicine University of California, Los Angeles, ***School of Medicine, University of California, Irvine, USA. ${ }^{+}$Faculty of Medicine, University of Toronto, Canada.

Correspondence: A.F. Gelb, 3650 E. South St. Suite 308, Lakewood, CA 90712, USA, Fax: 15626332579

Keywords: $\alpha_{1}$-Antitrypsin deficiency emphysema, lung elastic recoil, lung function, lung volume reduction surgery

Received: March 161999

Accepted after revision July 311999

M. Brenner was supported by Dept of Energy Grant No. DE-FG03-91ER61227, American Lung Association Grant No. CI-030-N, California Tobacco Related Disease Research Program No. 6RT-0158. lobe emphysema is due to a combination of loss of lung elastic recoil as well as intrinsic small airway abnormalities [4]. Following LVRS, the improvement in expiratory airflow is due to increased lung elastic recoil and small airway calibre [4].

The present study evaluated serial physiological changes in lung function, including the mechanism(s) of expiratory airflow limitation following bilateral LVRS in mild or nonsmokers with $\alpha_{1}$-AT deficiency emphysema, and compared them to results in non- $\alpha_{1}$-AT emphysema. The results indicated that the mechanism of loss of and subsequent improvement in expiratory airflow is directly related to the initial loss of and increase in lung elastic recoil pressure and its secondary effect on increasing small airways diameter. However, the improvement in FEV1 was modest, similar to that found in the results of CASSINA et al. [3].

\section{Methods}

\section{Patient selection}

Six patients (five males) aged $61 \pm 9$ yrs (mean \pm SD) were studied. All of the referred patients had homozygous PiZZ $\alpha_{1}$-AT deficiency with serum levels of $<11 \mu \mathrm{m}$. Cases 2 and 6 were nonsmokers, whereas cases 1 and 3-5 reported smoking for 56, 16, 38 and 32 pack-yrs respectively. All patients were nonsmokers for $\geq 5$ yrs prior to LVRS. 
Three of the patients (cases 1, 3 and 5) received intermittent monthly intravenous AT replacement therapy for up to $1-5$ yrs prior to surgery.

The authors criteria for operative intervention have been previously published $[4,7,8]$. The predominant sites of emphysematous destruction on lung computed tomography (CT) were in lower lung fields with relative preservation of normal lung tissue in upper lung fields. Standard nuclear medicine perfusion lung scans demonstrated similar heterogeneous distribution.

The patients in the present study were selected for LVRS because they were markedly dyspnoeic, of grade $\geq 3$ (unable to walk $>100 \mathrm{~m}$ ), and unable to perform routine daily activities [9]. They had severe expiratory airflow limitation, which did not improve despite maximal medical bronchodilator therapy including trial(s) of corticosteroids. Their exercise tolerance and dyspnoea did not improve sufficiently following physical therapy and pulmonary rehabilitation.

\section{Operative Techniques}

Informed consent was obtained from every patient who underwent sequential bilateral video-assisted thoracoscopic stapled LVRS as previously reported $[4,7,8]$. Targeted lung resection included lower lobes bilaterally, unless there was good isolated perfusion to superior segments, in which case they were spared. The shaving technique usually employed by the authors for upper lung field emphysema was not used.

Case 1 underwent right $(150 \mathrm{~g})$ and left $(107 \mathrm{~g})$ lower lobectomy; case 2 removal of right ( $80 \mathrm{~g})$ and left $(85 \mathrm{~g})$ lower four basilar segments; case 3 right (152 g) lower lobectomy and left four basilar segmentectomy (140 g); case 4 right (116 g) and left (117 g) lower lobectomy; case 5 right $(89 \mathrm{~g})$ and left ( $88 \mathrm{~g})$ four basilar segmentectomy; and case 6 various right $(129 \mathrm{~g})$ and left $(63 \mathrm{~g})$ lower lobe segmentectomy including upper segments.

\section{Lung function studies}

After obtaining informed consent, lung function studies were performed using similar techniques and equipment to that previously published $[4,10,11]$. All patients underwent routine lung function studies including maximum expiratory flow $\left(V^{\prime} \max \right) /$ volume (MEFV) curves and singlebreath diffusing capacity for carbon monoxide $(D \mathrm{~L}, \mathrm{CO})$. Thoracic gas volume and inspiratory airway resistance were measured at a panting frequency of $\leq 1 \mathrm{~Hz}$ in the plethysmograph. All tests were performed when the patients were clinically stable, using a pressure-compensated flow plethysmograph (Model 6200 Autobox; SensorMedics, Inc., Yorba Buena, CA, USA), and results compared to predicted values $[4,10,11]$. All studies were carried out after three inhalations $(670 \mu \mathrm{g})$ of aerosolized salbutamol, and the increase in FEV1 in every patient was $<200 \mathrm{~mL}$ and in forced vital capacity (FVC) $<300 \mathrm{~mL}$.

As previously noted $[4,10-12]$, in cases $1-3$, measurements of static lung elastic recoil pressures (PL,st) were carried out in the open plethysmograph with the patient in the sitting position, after placement of a $10-\mathrm{cm}$-long balloon inflated with $0.5 \mathrm{~mL}$ air in the lower third of the oesophagus. After at least two inspirations to total lung capacity (TLC), static transpulmonary (mouth/oesophageal) pressures were recorded following stepwise 3-s inter- ruptions of exhalation against a closed shutter at different lung volumes. A minimum of five deflation curves were obtained for each patient, and a plot of best visual fit of the pooled data was drawn.

In addition to plethysmographic techniques in cases 13 , mid-inspiratory airway resistance during spontaneous tidal breathing was also calculated, by measuring changes in transpulmonary pressure and airflow using techniques previously described [13].

Using techniques reported previously [4, 10-12] to determine the mechanism of expiratory airflow limitation in chronic obstructive lung disease, $V^{\prime} \max$, obtained from the MEFV-curve was plotted against PL,st at corresponding lung volumes and $V^{\prime} \max / \mathrm{PL}$,st (MFSR) curves were constructed. The slope of the MFSR-curve between 70 and $30 \%$ of FVC represents the conductance of the intrinsic small airway segment $(G \mathrm{~s})$ [14]. Normal values had been obtained previously in seven healthy subjects aged 61-74 yrs, in whom $G$ s was $0.06 \pm 0.01 \mathrm{~L} \cdot \mathrm{kPa}^{-1} \cdot \mathrm{s}^{-1}$ (mean \pm SD) and PL,st at TLC $2.5 \pm 0.7 \mathrm{kPa}$ [12].

The small number of patients studied precluded statistical analysis.

\section{Results}

The average hospital stay was $6.7 \pm 2.6$ days (mean \pm SD). Prior to LVRS, the dyspnoea score [9] was $3.2 \pm 0.05$ $($ mean \pm SD) and improved in every patient by $\geq 1$ grade; at $27 \pm 6$ months following surgery, it was $2.2 \pm 0.05$. As shown in table 1, there was postoperative improvement in lung function in every patient. Furthermore, the improvement was sustained in the four patients with a follow-up of $\geq 22$ months. This included a persistent reduction in all static lung volumes, and a modest increase in vital capacity and DL,CO. The increase in FEV1 was minimal. Preoperatively, inspiratory airway resistance in cases 1-3 was $<0.7 \mathrm{kPa} \cdot \mathrm{s} \cdot \mathrm{L}^{-1}$ using plethysmographic and. nonplethysmographic techniques. The amount of lung tissue excised was similar to that in LVRS in non- $\alpha_{1}$-AT-deficient patients [4].

\section{Maximum expiratory flow/volume curve}

Postoperatively, there was a marked downward shift of the MEFV-curve to lower lung volumes, with a decrease in TLC, but more so in residual volume, and a resultant increase in FVC (fig. 1). Additionally, $V^{\prime}$ max at both effortdependent and -independent lung volumes increased post-LVRS compared to preoperative isovolume points. The decrease in residual volume reflects partial relief from premature airway closure and dynamic expiratory airway collapse. Although the increase in FEV1 is minimal, any increase is paradoxical with the decreased lung volume following LVRS.

\section{Expiratory static lung elastic recoil pressure curves}

Preoperatively, the PL,st at TLC was $0.93 \pm 0.1 \mathrm{kPa}$ compared to $1.1 \pm 0.1 \mathrm{kPa}$ in 12 patients with non $\alpha_{1}$-AT deficiency emphysema [4].

Postoperatively, in each patient, there was a marked almost parallel shift to the right of the expiratory PL,st volume curve of the lung due to increased PL,st compared to preoperative isovolume points (fig. 2). Furthermore, 
Table 1. - Physiological data in six patients who were studied before and after lung volume reduction surgery for $\alpha_{1}$ antitrypsin emphysema

\begin{tabular}{|c|c|c|c|c|c|c|c|c|c|c|}
\hline Time* & $\begin{array}{c}\mathrm{VC} \\
\mathrm{L}\end{array}$ & $\begin{array}{c}\mathrm{FVC} \\
\mathrm{L}\end{array}$ & $\begin{array}{l}\text { FEV1 } \\
\text { L }\end{array}$ & $\begin{array}{c}\text { TLC } \\
\mathrm{L}\end{array}$ & $\begin{array}{c}\text { FRC } \\
\text { L }\end{array}$ & $\begin{array}{c}\mathrm{s} G \mathrm{aw} \\
\mathrm{L} \cdot \mathrm{kPa}^{-1} \cdot \mathrm{s}^{-1}\end{array}$ & $\begin{array}{c}\mathrm{RV} \\
\mathrm{L}\end{array}$ & $\begin{array}{c}\text { DL,CO } \\
\operatorname{mmol} \cdot \mathrm{kPa} \cdot \\
\min ^{-1}\end{array}$ & $\begin{array}{l}\text { PL,st } \\
\mathrm{kPa}\end{array}$ & $\begin{array}{c}\mathrm{Sa}_{\mathrm{O}} \mathrm{O}_{2} \\
\%\end{array}$ \\
\hline \multicolumn{11}{|l|}{ Case 1} \\
\hline Preop & $\begin{array}{l}1.8 \\
(43)\end{array}$ & $\begin{array}{l}1.5 \\
(36)\end{array}$ & $\begin{array}{l}0.79 \\
(28)\end{array}$ & $\begin{array}{c}8.5 \\
(136)\end{array}$ & $\begin{array}{c}7.1 \\
(175)\end{array}$ & $\begin{array}{c}0.0028 \\
(12)\end{array}$ & $\begin{array}{c}6.7 \\
(266)\end{array}$ & $\begin{array}{l}0.05 \\
(40)\end{array}$ & 0.8 & 91 \\
\hline 10 months & $\begin{array}{l}3.3 \\
(79)\end{array}$ & $\begin{array}{l}3.2 \\
(78)\end{array}$ & $\begin{array}{l}1.2 \\
(44)\end{array}$ & $\begin{array}{c}6.7 \\
(108)\end{array}$ & $\begin{array}{c}4.6 \\
(114)\end{array}$ & $\begin{array}{c}0.0034 \\
(15)\end{array}$ & $\begin{array}{c}3.5 \\
(138)\end{array}$ & $\begin{array}{l}0.07 \\
(57)\end{array}$ & 1.2 & 94 \\
\hline 24 months & $\begin{array}{c}3.5 \\
(83)\end{array}$ & $\begin{array}{l}3.5 \\
(83)\end{array}$ & $\begin{array}{c}1.0 \\
(35)\end{array}$ & $\begin{array}{c}6.3 \\
(101)\end{array}$ & $\begin{array}{c}3.9 \\
(103)\end{array}$ & $\begin{array}{c}0.0035 \\
(15)\end{array}$ & $\begin{array}{c}2.8 \\
(109)\end{array}$ & $\begin{array}{l}0.08 \\
(64)\end{array}$ & 1.4 & 95 \\
\hline \multicolumn{11}{|l|}{ Case 2} \\
\hline Preop & $\begin{array}{l}3.5 \\
(82)\end{array}$ & $\begin{array}{c}3.4 \\
(79)\end{array}$ & $\begin{array}{c}1.1 \\
(37)\end{array}$ & $\begin{array}{c}8.4 \\
(136)\end{array}$ & $\begin{array}{c}5.6 \\
(155)\end{array}$ & $\begin{array}{l}0.0040 \\
(17)\end{array}$ & $\begin{array}{c}4.9 \\
(217)\end{array}$ & NA & 1.1 & 96 \\
\hline 15 months & $\begin{array}{l}3.7 \\
(85)\end{array}$ & $\begin{array}{l}3.7 \\
(85)\end{array}$ & $\begin{array}{l}1.1 \\
(37)\end{array}$ & $\begin{array}{c}8.1 \\
(132)\end{array}$ & $\begin{array}{c}5.9 \\
(159)\end{array}$ & $\begin{array}{l}0.0050 \\
(24)\end{array}$ & $\begin{array}{c}4.5 \\
(199)\end{array}$ & NA & 1.4 & NA \\
\hline 23 months & $\begin{array}{l}4.1 \\
(95)\end{array}$ & $\begin{array}{l}3.9 \\
(92)\end{array}$ & $\begin{array}{l}1.3 \\
(42)\end{array}$ & $\begin{array}{c}8.3 \\
(134)\end{array}$ & $\begin{array}{c}5.4 \\
(145)\end{array}$ & $\begin{array}{l}0.0040 \\
(17)\end{array}$ & $\begin{array}{c}4.2 \\
(184)\end{array}$ & NA & 1.4 & 95 \\
\hline 36 months & $\begin{array}{l}3.9 \\
(89)\end{array}$ & $\begin{array}{l}3.7 \\
(85)\end{array}$ & $\begin{array}{c}1.0 \\
(32)\end{array}$ & $\begin{array}{c}8.1 \\
(132)\end{array}$ & $\begin{array}{c}5.8 \\
(157)\end{array}$ & $\begin{array}{c}0.0030 \\
(13)\end{array}$ & $\begin{array}{c}4.2 \\
(184)\end{array}$ & NA & 1.3 & 95 \\
\hline \multicolumn{11}{|l|}{ Case 3} \\
\hline Preop & $\begin{array}{l}3.8 \\
(84)\end{array}$ & $\begin{array}{c}3.4 \\
(76)\end{array}$ & $\begin{array}{l}1.1 \\
(30)\end{array}$ & $\begin{array}{c}9.2 \\
(137)\end{array}$ & $\begin{array}{c}6.5 \\
(173)\end{array}$ & $\begin{array}{c}0.0040 \\
(17)\end{array}$ & $\begin{array}{c}5.4 \\
(225)\end{array}$ & $\begin{array}{l}0.10 \\
(50)\end{array}$ & 0.9 & 92 \\
\hline 22 months & $\begin{array}{c}4.4 \\
(98)\end{array}$ & $\begin{array}{c}3.4 \\
(76)\end{array}$ & $\begin{array}{c}1.3 \\
(35)\end{array}$ & $\begin{array}{c}8.4 \\
(126)\end{array}$ & $\begin{array}{c}5.4 \\
(144)\end{array}$ & $\begin{array}{c}0.0040 \\
(17)\end{array}$ & $\begin{array}{c}4.0 \\
(171)\end{array}$ & $\begin{array}{l}0.16 \\
(79)\end{array}$ & 1.0 & 92 \\
\hline \multicolumn{11}{|l|}{ Case 4} \\
\hline Preop & $\begin{array}{l}2.0 \\
(64)\end{array}$ & $\begin{array}{l}1.5 \\
(48)\end{array}$ & $\begin{array}{c}0.6 \\
(24)\end{array}$ & $\begin{array}{c}9.7 \\
(193)\end{array}$ & $\begin{array}{c}7.2 \\
(250)\end{array}$ & $\begin{array}{c}0.0033 \\
(12)\end{array}$ & $\begin{array}{c}6.4 \\
(316)\end{array}$ & $\begin{array}{l}0.02 \\
(15)\end{array}$ & NA & 91 \\
\hline 7 months & $\begin{array}{l}2.3 \\
(74)\end{array}$ & $\begin{array}{l}2.1 \\
(68)\end{array}$ & $\begin{array}{l}0.6 \\
(24)\end{array}$ & $\begin{array}{c}6.4 \\
(126)\end{array}$ & $\begin{array}{c}4.9 \\
(171)\end{array}$ & $\begin{array}{c}0.0037 \\
(12)\end{array}$ & $\begin{array}{c}4.1 \\
(203)\end{array}$ & $\begin{array}{l}0.04 \\
(30)\end{array}$ & NA & 95 \\
\hline 27 months & $\begin{array}{l}2.3 \\
(74)\end{array}$ & $\begin{array}{l}2.2 \\
(74)\end{array}$ & $\begin{array}{c}0.7 \\
(30)\end{array}$ & $\begin{array}{c}7.1 \\
(147)\end{array}$ & $\begin{array}{c}5.7 \\
(197)\end{array}$ & $\begin{array}{c}0.0033 \\
(12)\end{array}$ & $\begin{array}{c}4.9 \\
(259)\end{array}$ & $\begin{array}{l}0.05 \\
(38)\end{array}$ & NA & 94 \\
\hline \multicolumn{11}{|l|}{ Case 5} \\
\hline preop & $\begin{array}{l}4.3 \\
(83)\end{array}$ & $\begin{array}{l}3.9 \\
(74)\end{array}$ & $\begin{array}{c}1.2 \\
(31)\end{array}$ & $\begin{array}{c}9.4 \\
(128)\end{array}$ & $\begin{array}{c}6.3 \\
(224)\end{array}$ & $\begin{array}{l}0.0040 \\
(17)\end{array}$ & $\begin{array}{c}5.1 \\
(245)\end{array}$ & $\begin{array}{l}0.11 \\
(44)\end{array}$ & NA & 92 \\
\hline 6 months & $\begin{array}{l}4.9 \\
(94)\end{array}$ & $\begin{array}{l}4.9 \\
(94)\end{array}$ & $\begin{array}{c}1.4 \\
(36)\end{array}$ & $\begin{array}{c}8.8 \\
(120)\end{array}$ & $\begin{array}{c}5.8 \\
(207)\end{array}$ & $\begin{array}{c}0.0070 \\
(35)\end{array}$ & $\begin{array}{c}3.9 \\
(186)\end{array}$ & $\begin{array}{l}0.10 \\
(38)\end{array}$ & NA & 94 \\
\hline \multicolumn{11}{|l|}{ Case 6} \\
\hline Preop & $\begin{array}{c}3.4 \\
(75)\end{array}$ & $\begin{array}{l}2.9 \\
(64)\end{array}$ & $\begin{array}{c}0.7 \\
(19)\end{array}$ & $\begin{array}{l}10.8 \\
(159)\end{array}$ & $\begin{array}{c}9.1 \\
(230)\end{array}$ & $\begin{array}{l}0.0030 \\
(13)\end{array}$ & $\begin{array}{c}7.4 \\
(292)\end{array}$ & $\begin{array}{l}0.07 \\
(34)\end{array}$ & NA & 91 \\
\hline 1 month & $\begin{array}{l}3.5 \\
(77)\end{array}$ & $\begin{array}{l}3.3 \\
(74)\end{array}$ & $\begin{array}{c}1.2 \\
(33)\end{array}$ & $\begin{array}{c}8.3 \\
(122)\end{array}$ & $\begin{array}{c}6.6 \\
(168)\end{array}$ & $\begin{array}{c}0.0030 \\
(13)\end{array}$ & $\begin{array}{c}4.8 \\
(190)\end{array}$ & $\begin{array}{l}0.08 \\
(39)\end{array}$ & NA & NA \\
\hline 6 months & $\begin{array}{l}3.5 \\
(77)\end{array}$ & $\begin{array}{l}3.1 \\
(66)\end{array}$ & $\begin{array}{l}1.0 \\
(27)\end{array}$ & $\begin{array}{c}9.3 \\
(136)\end{array}$ & $\begin{array}{c}6.6 \\
(168)\end{array}$ & $\begin{array}{c}0.0030 \\
(13)\end{array}$ & $\begin{array}{c}5.8 \\
(229)\end{array}$ & $\begin{array}{l}0.08 \\
(39)\end{array}$ & NA & 94 \\
\hline \multicolumn{11}{|l|}{ Cases 1-4 } \\
\hline Preop & $\begin{array}{l}2.8 \pm 0.5 \\
(68 \pm 10)\end{array}$ & $\begin{array}{l}2.4 \pm 0.5 \\
(64 \pm 10)\end{array}$ & $\begin{array}{c}0.9 \pm 0.1 \\
(30 \pm 2)\end{array}$ & $\begin{array}{c}9.0 \pm 0.2 \\
(151 \pm 13)\end{array}$ & $\begin{array}{c}6.6 \pm 0.4 \\
(188 \pm 20)\end{array}$ & $\begin{array}{c}0.0035 \pm 0 \\
(15 \pm 3)\end{array}$ & $\begin{array}{c}5.9 \pm 0.4 \\
(256 \pm 22)\end{array}$ & $\begin{array}{c}0.06 \pm 0.02 \\
(35 \pm 9)\end{array}$ & $0.93 \pm 0.12$ & $93 \pm 2$ \\
\hline $27 \pm 6$ months & $\begin{array}{l}3.5 \pm 0.5 \\
(88 \pm 5)\end{array}$ & $\begin{array}{l}3.2 \pm 0.4 \\
(82 \pm 4)\end{array}$ & $\begin{array}{c}1.0 \pm 0.1 \\
(33 \pm 1\end{array}$ & $\begin{array}{c}7.5 \pm 0.5 \\
(127 \pm 10)\end{array}$ & $\begin{array}{c}5.2 \pm 0.5 \\
(148 \pm 17)\end{array}$ & $\begin{array}{c}0.0034 \pm 0 \\
(14 \pm 2)\end{array}$ & $\begin{array}{c}4.0 \pm 0.4 \\
(181 \pm 31)\end{array}$ & $\begin{array}{c}0.10 \pm 0.02 \\
(59 \pm 9)\end{array}$ & $1.2 \pm 0.10$ & $94 \pm 1$ \\
\hline
\end{tabular}

Data are presented with percentage predicted values in parentheses; pre- (preop) and postoperative values for cases $1-4$ are given as mean \pm SEM. *: shown as preop or time postoperation. VC: vital capacity; FVC: forced vital capacity; FEV1: forced expiratory volume in one second; TLC: total lung capacity; FRC: functional residual capacity; sGaw: specific airway conductance; RV: residual volume; DL,CO: single breath diffusing capacity of the lung for carbon monoxide; PL,st: static lung elastic recoil pressure (at total lung capacity; three patients); $\mathrm{Sa}_{2} \mathrm{O}_{2}$ : artenal oxygen saturation on room air at rest; NA: not available.

there was also an increase in PL,st at TLC despite a marked reduction in TLC postoperatively.

The improvement in lung elastic recoil persisted 24 months (case 1) 36 months (case 2) and 22 months (case 3) postoperatively, as shown in figure 2 and table 1 .

Maximum expiratory flow/static lung elastic recoil pressure curve

Preoperatively, the marked reduction in $V^{\prime} \max$ could be accounted for primarily by the marked reduction in lung elastic recoil since the slope of the MFSR-curve, i.e. Gs,
$0.057-0.078 \mathrm{~L} \cdot \mathrm{kPa}^{-1} \cdot \mathrm{s}^{-1}$, was similar to the slope of agematched normal subjects (fig. 3). This indicates that the resistance offered by intrinsic small airways disease was low.

Postoperatively, the increased $V^{\prime}$ max was predominantly due to increased lung elastic recoil because the extended MFSR Gs slope tended to parallel the preoperative MFSR $G$ s slope. The pre- and post- LVRS $G$ s are in contrast to those of chronic smokers without $\left(\alpha_{1}\right.$-AT deficiency who have a markedly reduced $G$ s slope because of severe intrinsic airway abnormalities limiting airflow despite loss of lung elastic recoil [4]. 


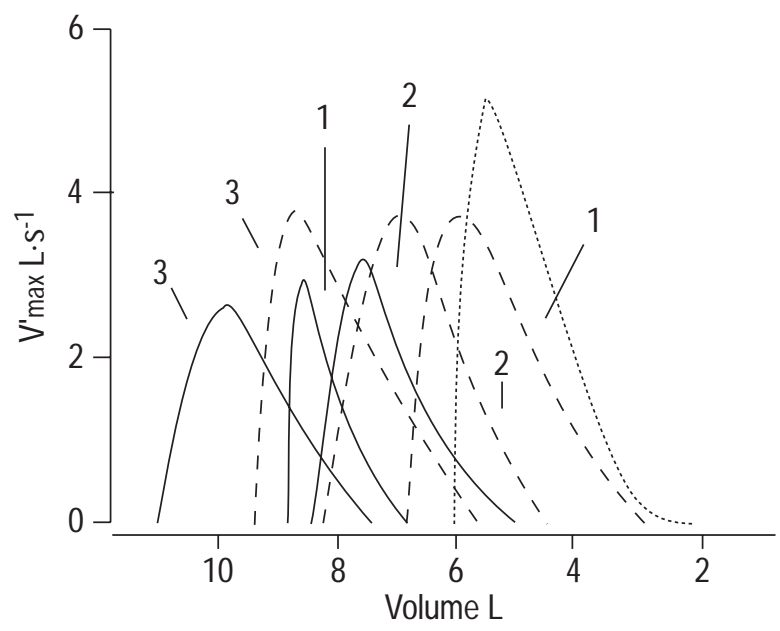

Fig. 1. - Maximum expiratory flow $\left(V^{\prime} \max \right) /$ volume curves at baseline $(-)$ and 24, 36 and 22 months post lung volume reduction surgery (LVRS) (-- ) in cases 1-3 respectively (number indicate case). There was a marked reduction in total lung capacity and residual volume with an increase in forced vital capacity and expiratory flow at isovolume points post-LVRS in each case. A normal curve is shown for comparison (- - - ).

Post-LVRS, two (cases 1 and 2) patients refused to continue augmentation therapy and the other four (cases 36) receive it every $2-4$ weeks.

\section{Discussion}

The results of the present study demonstrate clinical and physiological improvement in lung function following bilateral stapled lower lobe LVRS in symptomatic patients with PiZZ $\alpha_{1}$-AT deficiency emphysema and severe expiratory airflow limitation. The improvement in expiratory airflow associated with a decrease in static lung volumes following LVRS may be primarily attributable to an increase in lung elastic recoil and secondary effect on small

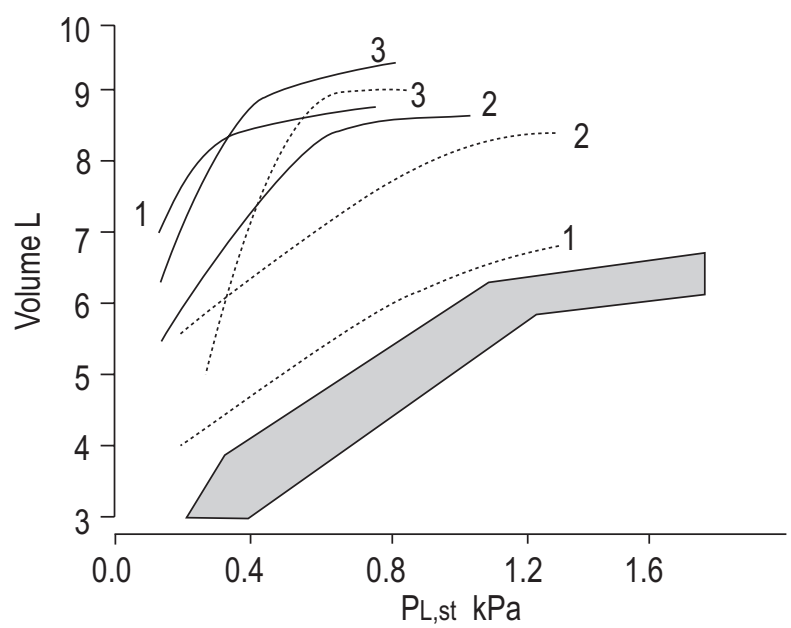

Fig. 2. - Static expiratory lung elastic recoil pressure (PL,st) curves in cases $1-3$ pre- (- ${ }^{-}$and post-lung volume reduction surgery (LRVS) $(---)$ (numbers indicate case). There was a marked increase in lung recoil pressure at all lung volumes including total lung capacity postLVRS despite a reduction in actual lung volumes. The normal range ( $\square$ ) is shown for comparison.

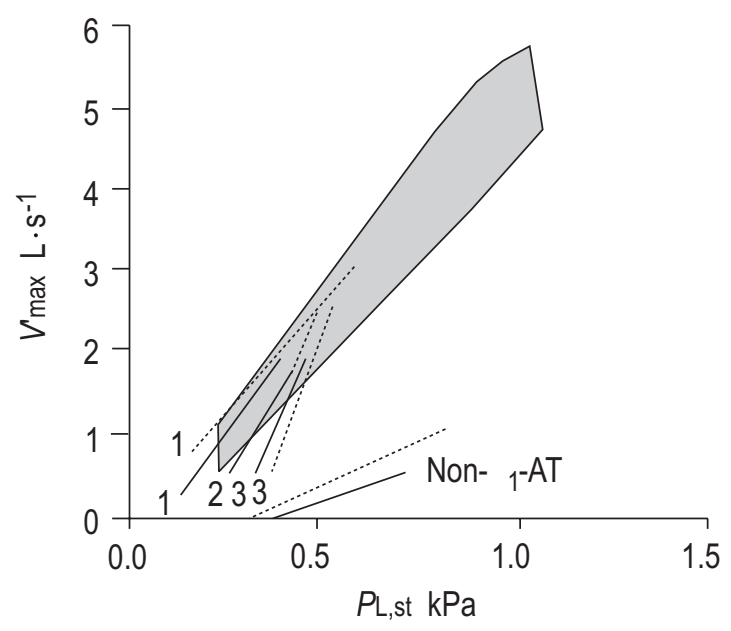

Fig. 3. - Maximum expiratory flow $\left(V^{\prime} \max \right) /$ static lung elastic recoil pressure (PL,st) curves for cases 1-3. The pre-lung volume reduction surgery (LVRS) conductance of small airways $\left(G_{\mathrm{s}}\right)(-)$ falls mostly within the normal range ( $\square$ ) suggesting expiratory airflow limitation was predominantly due to loss of lung elastic recoil, and intrinsic small airways disease was mild. Post-LVRS $(---)$, the $G$ s suggested increased expiratory airflow was due to increased lung elastic recoil. Data were obtained at effort-independent lung volumes. Mean values for pre(- ) and 24 month post-LVRS (- - ) are also shown for 12 non- $\alpha_{1-}$ antitrypsin (AT) deficient emphysematous patients who were chronic cigarette smokers [4].

airway calibre $[4,10]$. The improvement persisted in all four patients studied $22,24,27$ and 36 months postLVRS.

However, the present results are partly in contrast to those of CASSINA et al. [3] who noted only a transient 6-12 month functional improvement in spirometric results and lung volumes in 12 patients who underwent LVRS for $\alpha_{1-}$ AT deficiency-associated emphysema and were followed for 2 yrs. Only dyspnoea scores [9] and 6-min walking distance remained improved compared to baseline up to 12 months post-LVRS [3].

The patients in the study of CASsinA et al. [3] compared to those in the present study, were younger, aged $49 \pm 10$ yrs (mean $\pm \mathrm{SD})$, but had similar baseline smoking history and dyspnoea scores [9]. However, their baseline lung function suggested greater airflow obstruction; the mean FEV1 was $0.8 \mathrm{~L}$ (24\% pred) and plethysmographic mean airway resistance $0.59 \mathrm{kPa} \cdot \mathrm{s} \cdot \mathrm{L}^{-1}$, compared $0.9 \mathrm{~L}(30 \%$ pred) and $0.43 \mathrm{kPa} . \mathrm{s} \cdot \mathrm{L}^{-1}$, respectively, in the present study. All had been receiving Prolastin for $\geq 2$ yrs prior to LVRS and continued to receive it post-LVRS [3].

The conflicting results may, in part, be related to the extent of surgical resection, i.e. lobectomies versus shaving. However, 18 non- $\alpha_{1}$-AT emphysema patients who underwent bilateral LVRS in the study of CASSINA et al. [3] achieved similar $2 \mathrm{yr}$ results to the present non- $\alpha_{1}$-AT patients $[4,7]$.

\section{Mechanism(s)}

The PL,st/volume curves of cases 1-3 pre-LVRS were shifted markedly to the left of normal (fig. 2), consistent with severe loss of lung elastic recoil. It is the severe loss of lung elastic recoil that is responsible for the marked increase in TLC, as well as the marked decrease in 
expiratory airflow (fig. 3). Although loss of lung elastic recoil is the physiological sequela of emphysematous lung destruction, it has recently been shown that loss of lung elastic recoil can also result from unknown mechanism(s) in chronic-cigarette smoking patients who show severe fixed intrinsic obstruction and/or obliteration of the small airways [11]. They exhibit marked expiratory airflow limitation and hyperinflation at TLC in the presence of no or trivial emphysema on lung CT as well as accompanying necropsy specimens. However, in the present cases, the preoperative lung CT and postoperative resected lung demonstrated very advanced emphysematous destruction.

Following LVRS similar to that in the present study, the present $[4,10]$ and other authors $[15,16]$ have reported a modest increase in lung elastic recoil. However, in all studies post-LVRS, PL,st, $V^{\prime} \max$ and $D$ L,CO remain markedly abnormal, reflective of the underlying diffuse emphysema. The small increase in $D \mathrm{~L}, \mathrm{CO}$ noted in the present and previous reports $[4,10]$ probably reflects a greater alveolar capillary surface area due to less tissue compression and increased transpulmonary pressure following LVRS.

The authors believe that the improvement in $V^{\prime} \max$ and FVC following LVRS in the present study is primarily due to an increase in lung elastic recoil and secondary increase in airway diameter following excision of the worst affected emphysematous lung, allowing expansion of less involved lung.

The increased PL,st provides both greater driving pressure for expiratory airflow and increased alveolar support to tether airways, preventing them from collapsing during exhalation. It also decreases TLC and limits hyperinflation by reducing premature airway closure and dynamic collapse. Analysis of the preoperative MFSR - curves indicates that $V^{\prime} \max$ was predominantly limited by loss of lung elastic recoil, similar to previous observations in other nonsmoking patients with $\alpha_{1}$-AT deficiency [17]. This is in contrast to previous studies [14] and the authors LVRS experience with non $\alpha_{1}$-AT patients with severe emphysema, in whom severe expiratory airflow limitation is caused by both loss of lung elastic recoil and suspected intrinsic obstruction and/or obliteration of the small airways, as reflected in a markedly reduced $G$ s (fig. 3) [4, $10]$. This is probably due to the predominant site of small airway pathology in centrilobular emphysema in patients with a history of chronic heavy cigarette smoking [12, 18-22]. Although it is not known whether intrinsic small airway abnormalities cause or complicate centrilobular emphysema, it is the predominant site of expiratory airflow limitation in patients who die because of severe non- $\alpha_{1}$-AT severe emphysema [18]. It is suspected that intrinsic small airway disease is less prominent in mildto-moderate centrilobular emphysema [12, 19-23], and in severe panlobular emphysema [20], especially in non- or mild smokers, as in the present study. Furthermore. inspiratory airway resistance was only mildly elevated in cases $1-3$, in keeping with previous observations associated with improved short-term outcome following LVRS [24]. The ability to choose emphysematous patients with a paucity of cigarette smoking history and small airway abnormalities for LVRS would intuitively appear to enhance the projects of a successful outcome. Yet the results in the present study and those of CASSINA et al. [3] do not demonstrate similar physiological improvement to that observed following LVRS in non- $\alpha_{1}$-AT deficient emphysematous smokers with similar expiratory airflow limitation and inspiratory airway resistance prior to LVRS [4]. The present results tend to reflect the minor improvement in FEV1, noted after LVRS in symptomatic patients with severe expiratory airflow limitation without $\alpha_{1}$-AT deficiency following bilateral lower lobe target resection [8]. The authors' unpublished observations in one patient indicated airflow limitation was due to both loss of lung elastic recoil and intrinsic obstruction of the small airways (reduced $G$ s), similar to non- $\alpha_{1}$-AT deficiency in the upper lobes $[4,10]$.

The variable physiological response among the patients in the present study does not appear to be accounted for by differences in baseline lung function studies or the amount of tissue resected, similar to previous observations [4].

Following LVRS, several investigators have emphasized the increase in respiratory/inspiratory muscle strength and transdiaphragmatic pressure $[16,25-28]$ with relief of dyspnoea $[16,25-31]$ associated with decreased hyperinflation [16, 25-31] with improved breathing pattern [31] and neuromuscular coupling of the diaphragm [28]. However, the present authors believe that these changes are secondary to the reduction in hyperinflation due to increased lung elastic recoil.

It is unlikely, post-LVRS, that intermittent nonweekly intravenous Prolastin therapy would have any beneficial effect on maintaining increased airflow in cases 3-6, with persistent severe expiratory airflow limitation, especially since it had not shown benefit prior to LVRS in cases 3 and 5. Furthermore, cases 1 and 2 refused Prolastin post-LVRS, yet showed sustained improved lung function 24 and 36 months following LVRS.

Despite the small number of patients in the present study, precluding meaningful statistical analysis, the reduced PL,st at TLC compared to that in non- $\alpha_{1}$-AT emphysematous patients suggests an overall greater amount of parenchymal destruction and may help to explain the reduced post-LVRS improvement compared to that in non$\alpha_{1}$-AT emphysema. Greater parenchymal destruction and suboptimal post-LVRS improvement has also been noted in $\alpha_{1}$-AT deficient patients compared to non- $\alpha_{1}$-AT emphysema (personal communication, J. Cooper, St Louis, MO, USA).

In summary, 2-3 yrs of follow-up of lower lobe lung volume reduction surgery in four patients with $\alpha_{1}$-antitrypsin emphysema suggests the physiological changes may be attributed to increased lung elastic recoil. Further investigative studies will be needed to define the clinical role if any of lung volume reduction surgery in $\alpha_{1}$-AT emphysema.

\footnotetext{
Acknowledgements. The authors thank R. Newsom for technical assistance.
}

\section{References}

1. The Alpha-1 Antitrypsin Deficiency Registry Study Group. Survival and FEV1 decline in individuals with severe deficiency of $\alpha_{1}$-antitrypsin. Am J Respir Crit Care Med 1998; 158: 49-59. 
2. Seersholm N, Wencker M, Banik N, Vistum K, Dirksen A, Kok-Jensen A, for the "Wissenschaftliche Arbeitsgemeinschaft zur therapie von Lungenerkrankungen (WATL) $\alpha_{1}$-AT study group." Does $\alpha_{1}$-antitrypsin augmentation therapy slow the annual decline in FEV1 in patients with severe hereditary $\alpha_{1}$-antitrypsin deficiency? Eur Respir J 1997; 10: 2260-2263.

3. Cassina PC, Teschler H, Konietzko N, Theegarten D, Stamatis G. Two-year results after lung volume reduction surgery in $\alpha_{1}$-antitrypsin deficiency versus smoker's emphysema. Eur Respir J 1998; 12: 1028-1032.

4. Gelb AF, Brenner M, McKenna Jr RJ, Fischel R, Zamel N, Schein MJ. Serial lung function and elastic recoil 2 years after lung volume reduction surgery for emphysema. Chest 1998; 113: 1497-1506.

5. Cooper JD, Patterson GA, Sundaresan RS, et al. Results of 150 consecutive bilateral lung volume reduction procedures in patients with severe emphysema. $J$ Thorac Cardiovasc Surg 1996; 112: 1319-1330.

6. Roue $\mathrm{C}, \mathrm{Mal} \mathrm{H}$, Sleiman $\mathrm{C}$, et al. Lung volume reduction in patients with severe diffuse emphysema: a retrospective study. Chest 1996; 110: 28-34.

7. Brenner M, McKenna Jr RJ, Chen JC, et al. Survival following bilateral stapled lung volume reduction surgery for emphysema. Chest 1999; 115: 390-396.

8. McKenna RJ Jr, Brenner M, Fischel R, et al. Patient selection criteria for lung volume reduction surgery. $J$ Thorac Cardiovasc Surg 1997; 114: 957-964.

9. Task Group on Screening for Respiratory Disease in Occupational Settings. Official Statement of the American Thoracic Society. Am Rev Respir Dis 1982; 126: 952956.

10. Gelb AF, McKenna Jr RJ, Zamel N. Mechanism of shortterm improvement in lung function following emphysema resection. Am J Respir Crit Care Med 1996; 945-951.

11. Gelb AF, Zamel N, Hogg JC, Müller NL, Schein MJ. Pseudophysiologic emphysema resulting from severe small-airways disease. Am J Respir Crit Care Med 1998; 158: 815-819.

12. Zamel N, Hogg JC, Gelb AF. Mechanisms of maximal expiratory flow limitation in clinically unsuspected emphysema and obstruction of the peripheral airways. $\mathrm{Am}$ Rev Respir Dis 1976; 113: 337-345.

13. Mead J, Whittenberger JL. Physical properties of human lungs measured during spontaneous respiration. $J \mathrm{Appl}$ Physiol 1953; 5: 779-783.

14. Leaver DG, Tattersfield AE, Pride NB. Contribution of loss of lung recoil and of enhanced airways collapsibility to the airflow obstruction in chronic bronchitis and emphysema. J Clin Invest 1973; 52: 2117-2128.

15. Sciurba FC, Rogers RM, Keenan RJ, et al. Improvement in pulmonary function and elastic recoil after lung reduction surgery for diffuse emphysema. N Engl J Med 1996; 334: 1095-1099.

16. Martinez FJ, Montes de Oca M, Whyte TI, Stetz J, Gay SE, Celli BR. Lung volume reduction improves dyspnea, dynamic hyperinflation and respiratory muscle function. Am J Respir Crit Care Med 1997; 155: 1984-1990.

17. Black LE, Hyatt RE, Stubbs SE. Mechanism of expiratory airflow in chronic obstructive lung disease associated with $\alpha$ l-antitrypsin deficiency. Am Rev Respir Dis 1972; 105: 891-899.

18. Hogg JC, Macklem PT, Thurlbeck WM. Site and natfire of airway obstruction in chronic obstructive lung disease. N Engl J Med 1968; 278: 1355-1360.

19. Hogg JC, Wright JL, Wiggs BL, Coxson HO, Saez AO, Pare PD. Lung structure and function in cigarette smokers. Thorax 1994; 49: 473-478.

20. Kim WD, Eidelman DH, Izquierdo JL, Ghezzo H, Saetta MP, Cosio MG. Centrilobular and panlobular emphysema in smokers: two distinct morphologic and functional entities. Am Rev Respir Dis 1991; 144: 1385-1390.

21. Gelb AF, Hogg JC, Müller NL, et al. Contribution of emphysema and small airways in COPD. Chest 1996; 109: 353-359.

22. Gelb AF, Gold WM, Wright RR, Bruch HR, Nadel JA. Physiologic diagnosis of subclinical emphysema. Am Rev Respir Dis 1973; 107: 571-578.

23. Jeffrey PK. Pathology of asthma and COPD: a synopsis. Eur Respir Rev 1997; 7: 43, 111-118.

24. Ingenito EP, Evans RP, Loring SH, et al. Relation between preoperative inspiratory lung resistance and the outcome of lung volume reduction surgery for emphysema. N Engl J Med 1998; 338: 1181-1185.

25. O'Donnell DE, Webb KA, Bertley JC, Chaul KL, Conlan AA. Mechanisms of relief of exertional breathlessness following unilateral bullectomy and lung volume reduction surgery in emphysema. Chest 1996; 110: 18-27.

26. Benditt JO, Wood DE, McCool FD, Lewis S, Albert RK. Changes in breathing and ventilatory muscle recruitment patterns induced by lung volume reduction surgery. $\mathrm{Am} \mathrm{J}$ Respir Crit Care Med 1997; 155: 279-284.

27. Teschler H, Stamatis G, El-Raouf Farhatt AA, et al. Effect of surgical lung volume and respiratory muscle function in pulmonary emphysema. Eur Respir J 1996; 9: 17791784.

28. Laghi F, Jubran A, Topeli A, et al. Effect of lung volume reduction surgery on neuromechanical coupling of the diaphragm. Am J Resp Crit Care Med 1998; 157: 475483 .

29. Keller CA, Ruppell G, Hibbett A, et al. Thoracoscopic lung volume reduction surgery reduces dyspnea and improves exercise capacity in patients with emphysema. $\mathrm{Am}$ J Respir Crit Care Med 1997; 156: 60-67.

30. Benditt JO, Lewis $\mathrm{S}$, Wood $\mathrm{DE}$, et al. Lung volume reduction surgery improves maximal $\mathrm{O}_{2}$ pulse, and dead space-to-tidal volume ratio during leg cycle ergometry. Am J Respir Crit Care Med 1997; 156: 561-66.

31. Bloch KE, Li Y, Zhang J, Bingisser R, Kaplan V, Russi EW. Effects of surgical lung volume reduction surgery on breathing patterns in severe pulmonary emphysema. Am J Respir Crit Care Med 1997; 156: 553-560. 